\title{
Meningkatkan Hasil Belajar Siswa Melalui Media Permainan Let's Play
}

\author{
Apri Utami Parta Santi ${ }^{1}$, Nur Amalina ${ }^{2}$ \\ 1) Fakultas Ilmu Pendidikan; Universitas Muhammadiyah Jakarta; Jakarta; \\ apri.santi@umj.ac.id \\ 2) Fakultas Ilmu Pendidikan; Universitas Muhammadiyah Jakarta; Jakarta; \\ nuramalina917@gmail.com
}

\begin{abstract}
Abstrak. Penelitian ini bertujuan untuk mendeskripsikan peningkatan hasil belajar matematika khususnya materi tentang uang melalui penggunaan media permainan Let's Play. Subyek penelitian ini adalah seluruh siswa kelas III B di SD Negeri Pengasinan 03 Depok, sebanyak 36 siswa. Data yang dikumpulkan melalui lembar observasi, tes tertulis dan dokumentasi. Penelitian ini dilaksanakan di SD Negeri Pengasinan 03 Depok, Kelurahan Pengasinan, Kecamatan Sawangan, Kota Depok, khususnya kelas III. Penelitian ini dilakukan dengan metode siklus yang mengacu pada model Penelitian Tindakan Kelas (PTK) Kemmis and Mc. Taggart sebanyak dua siklus, yaitu siklus I dan siklus II. Hasil penelitian menunjukkan bahwa hasil belajar siswa mata pelajaran matematika khususnya materi uang melalui penggunaan media permainan Let's Play pada siklusnya mengalami peningkatan dari $44,44 \%$ pada siklus I menjadi $88,89 \%$ pada siklus II, sehingga telah mencapai kriteria keberhasilan yang diharapkan. Penggunaan media permainan Let's Play dalam pembelajaran matemtika dapat membantu siswa menjadi lebih aktif dalam proses pembelajaran dan melatih kerjasama dalam kelompok.
\end{abstract}

Kata kunci: let's play, hasil belajar, matematika, materi pembelajaran uang dan penelitian tindakan kelas

Abstract. This study aims to describe the improvement of mathematics learning outcomes, especially material about money through the use of Let's Play media. The subjects of this study were all students of class III B in Pengasinan 03 Depok Elementary School, totaling 36 students. Data collected through observation sheets, written tests and documentation. This research was conducted at Depok Pengasinan 03 Elementary School, Pengasinan Village, Sawangan District, Depok City, especially in class III. This research was conducted by a cycle method that refers to the Classroom Action Research (CAR) model of Kemmis and Mc. Taggart for two cycles, namely cycle I and cycle II. The results showed that students' learning outcomes in mathematics especially money material through the use of Let's Play media in the cycle increased from $44.44 \%$ in the first cycle to $88.89 \%$ in the second cycle, so that it had reached the expected success criteria. The use of Let's Play game media in mathematics learning can help students become more active in the learning process and practice collaboration in groups.

Caruban : Jurnal Ilmiah Pendidikan Dasar 2(1), 1-10, Januari 2019

p-ISSN 2615-1391, e-ISSN 2620-3219 @Prodi PGSD Universitas Swadaya Gunung Jati 
Keywords: let's play, learning outcomes, mathematics, money learning materials and classroom action research

\section{Pendahuluan}

Perkembangan Ilmu Pengetahuan dan Teknologi (IPTEK) menyebabkan kemajuan peradaban manusia semakin cepat, salah satunya dalam bidang pendidikan. Oleh karena itu, untuk memenuhi tuntutan kemajuan IPTEK tersebut, manusia dituntut untuk mencapai pendidikan yang setinggi- tingginya, dengan pendidikan manusia dapat mengembangkan segala bakat dan potensi yang dimilikinya serta dapat menjadi manusia yang bertanggung jawab dan bertakwa kepada Tuhan Yang Maha Esa.

Sekolah Dasar (SD) merupakan satuan pendidikan formal pertama yang mempunyai tanggung jawab untuk dapat mengembangkan sikap dan kemampuan dasar bagi siswa agar dapat menyesuaikan diri di tengah masyarakat. Proses pembelajaran seharusnya berlangsung secara menyenangkan, sehingga akan membuat siswa mudah menerima pelajaran tanpa paksanaan dan tekanan.

Permasalahan pada pembelajaran konvensional dapat diatasi dengan penerapan pembelajaran inovatif. Pembelajaran inovatif merupakan pembelajaran yang mampu menarik perhatian siswa melalui pelibatan aktif siswa yang bersangkutan. Berkaitan dengan hal tersebut, perlu dirancang suatu kegiatan belajar yang menarik bagi siswa (Isjoni, 2008: 7)

Dalam proses belajar mengajar, lima komponen yang sangat penting adalah tujuan, materi, metode, media, dan evaluasi pembelajaran. Kelima aspek ini saling mempengaruhi. Sebagai salah satu komponen pembelajaran, media tidak bisa luput dari pembahasan sistem pembelajaran secara menyeluruh. Pemanfaatan media seharusnya merupakan bagian yang harus mendapat perhatian pendidik dalam setiap kegiatan pembelajaran, namun kenyataanya bagian inilah yang masih sering terabaikan dengan berbagai alasan yang sering muncul antara lain: terbatasnya waktu untuk membuat persiapan mengajar, sulitnya mencari media yang tepat, tidak tersedianya biaya dan lain-lain.

Belajar merupakan aktifitas atau pengalaman yang menghasilkan perubahan pengetahuan, prilaku, dan pribadi yang bersifat permanen. 
Perubahan itu dapat bersifat penambahan atau pengayaan pengetahuan, prilaku, dan kepribadian.

Menurut Susanto (2016: 5) Hasil belajar yaitu perubahan-perubahan yang terjadi pada diri siswa, baik yang menyangkut aspek kognitif, afektif dan psikomotorik sebagai hasil dari kegiatan belajar. Secara sederhana, yang dimaksud hasil belajar siswa adalah kemampuan yang diperoleh anak setelah melalui kegiatan belajar.

Secara umum faktor-faktor yang mempengaruhi hasil belajar dibedakan atas dua kategori, yaitu faktor internal dan faktor eksternal. Kedua faktor tersebut saling memengaruhi dalam proses belajar individu sehingga menentukan kualitas hasil belajar seseorang.

Menurut Robert Gagne dalam W.S.Winkel (2009: 111) meninjau hasil belajar yang harus dicapai oleh siswa dimasukkan dalam lima kategori antara lain: informasi verbal (verbal information), kemahiran intelektual intellectual skill), pengaturan kegiatan kognitif (cognitive strategy), keterampilan motorik (motor skill), sikap (attitude).

Hasil belajar siswa dapat ditingkatkan melalui berbagai macam yang dilakukan oleh guru, salah satunya dengan penggunaan media pembelajaran. Media pembelajaran yang digemari oleh siswa terutama pada siswa kelas rendah yaitu media yang terdapat unsur permainan, sehingga siswa dapat merasakan suasana belajar sambil bermain. Menurut Sadiman et al. (2010:7) media adalah segala sesuatu yang dapat digunakan untuk menyalurkan pesan dari pengirim ke penerima sehingga dapat merangsang pikiran, perasaan, perhatian, dan minat serta perhatian sedemikian rupa sehingga proses belajar terjadi.

Riana (2008:196) mengemukakan sebuah media yang efektif dan efisien serta menyenangkan tentu menjadi dambaan dan kebutuhan untuk pembelajaran, untuk mendapatkan media tersebut diperlukan beberapa prinsip yang perlu diperhatikan dalam pemilihan media. Sejumlah pertimbangan dalam memilih media pembelajaran yang tepat dapat kita rumuskan dalam satu kata ACTION, yaitu akronim dari; Access, Cost, Technology, Interactivity, Organization, dan Novelty. 
Gunadi dan Misriandi (2014: 99) mengelompokkan jenis media yang biasa digunakan dalam proses pembelajaran antara lain media visual, media audio dan media audiovisual.

Sadiman, et al. (2010: 75) menyebutkan bahwa permainan adalah setiap kontes antar pemain yang berinteraksi satu sama lain dengan mengikuti aturan-aturan tertentu untuk mencapai tujuan-tujuan tertentu pula. Sadiman, et al. (2010: 78) menyebutkan kelebihan permainan sebagai media pendidikan, antara lain : menarik perhatian dan minat siswa, memungkinkan adanya partisipasi aktif, memberikan umpan balik langsung, memungkinkan penerapan konsep dan peran secara langsung, bersifat luwes, mudah dibuat dan diperbanyak.

Game edukasi menjadi salah satu media yang efektif digunakan sebagai media belajar bagi anak karena dengan media game anak akan merasa senang dan tertarik untuk memainkannya, selain itu dengan game edukasi anak dapat sekaligus belajar dan bermain sesuai dengan konten yang ada dalam game. Dimana ketika memainkan game pemain dapat melakukan berbagai interaksi dan pengambilan keputusan dengan mempertimbangkan berbagai kondisi. Menurut penelitian ketika memainkan game, anak mengalami pengalaman yang jauh melebihi apa yang mereka dapatkan di kelas (Henry, 2010).

Media permainan Let's Play dapat menjadi salah satu media yang digunakan didalam proses pembelajaran. Kata Let's Play berarti mari main, maksudnya ialah permainan ini mengajak untuk orang-orang ikut berpartisipasi atau ikut bermain dalam permainan ini, khususnya dalam hal ini ialah mengajak kepada siswa bermain di dalam proses pembelajaran terkait suatu materi yang sedang dipelajari.

Media permainan Let's Play adalah suatu media permainan yang dikemas dalam suatu permainan seperti permainan monopoli. Dalam permianan Let's Play ini di setiap kotak pertanyaan untuk diri sendiri dan juga pertanyaan untuk temanmu, diisi dengan teori atau ulasan mengenai Uang, mulai dari penulisan dan penyebutan berbagai nilai mata uang rupiah, kesetaraan nilai uang, dan lain-lain. Permainan Let's Play memerlukan pemahaman, dan ketangkasan para pemain dalam memahami 
bacaan setiap kotak, karena akan memudahkan dalam menjawab pertanyaan.

Perlengkapan yang dibutuhkan dalam permainan Let's Play:

1. Sebuah papan permainan yang dibuat dengan ukuran $50 \mathrm{~cm} \times 50 \mathrm{~cm}$

2. Dadu 1 buah beserta wadahnya

3. Poin sebanyak jumlah banyaknya pemain

4. 1 set kartu pertanyaan diri sendiri dan 1 set kartu pertanyaan untuk temanmu

5. Uang-uang mainan dari berbagai pecahan nilai mata uang

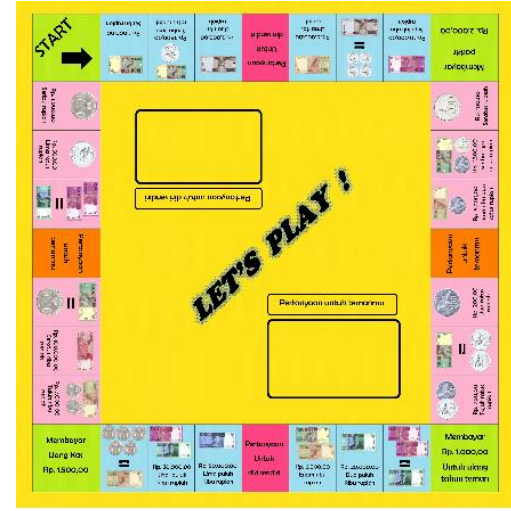

Gambar 1. Papan media permainan Let's Play

\section{Metode Penelitian}

Penelitian ini dilakukan di SD Negeri Pengasinan 03, Kecamatan Sawangan, Kelurahan Pengasinan, Kota Depok. Penelitian ini dilaksanakan mulai bulan November 17 sampai bulan April 2018.

Metode penelitian yang digunakan adalah metode Penelitian Tindakan Kelas (PTK). Penelitian Tindakan Kelas adalah proses pengkajian masalah pembelajaran di dalam kelas melalui refleksi diri dan upaya untuk memecahkannya dengan cara melalukan berbagai tindakan yang tererncana dalam situasi nyata serta menganalisis setiap pengaruh dari tindakan tersebut (Sanjaya, 2014: 149).

Pelaksanaan Penelitian Tindakan Kelas ini dilakukan dengan menggunakan model desain Kemmis dan Mc. Taggart. 


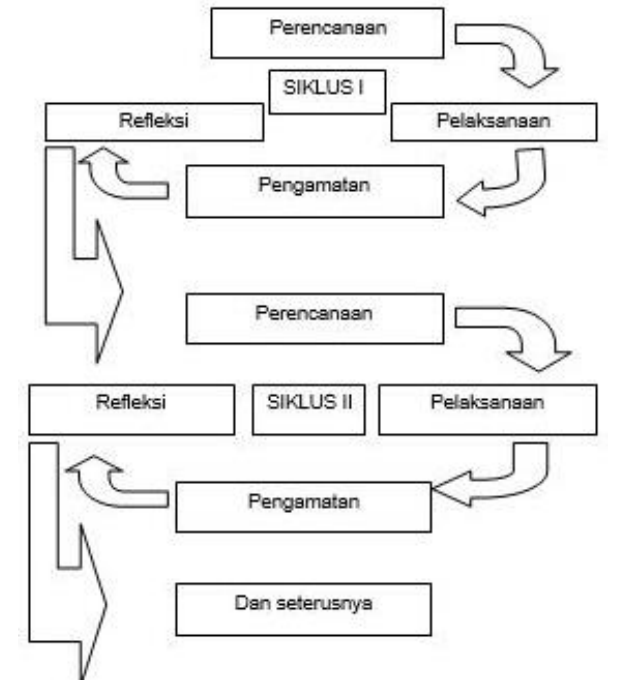

Gambar 2. Model PTK menurut Kemmis and Mc.Taggart

Model Kemmis dan Mc. Taggart dilaksanakan dalam bentuk siklus yang berulang-ulang, yang mencakup mpat langkah yaitu perencanaan (planning), pelaksanaan (acting), pengamatan (observing), dan refleksi (reflecting).

Pengumpulan data dalam penelitian ini dilakukan dengan menggunakan lembar observasi/ pengamatan, tes, dan dokumentasi. Lembar pengamatan aktivitas guru dilakukan oleh guru kelas/ kolaborator sebagai observer untuk mengambil data peneliti saat melakukan proses pembelajaran. Lembar pengamatan aktivitas siswa dilakukan oleh peneliti untuk mengetahui perkembangan dan ketepatan interaksi antara siswa dengan siswa, dan perkembangan siswa dalam memahami materi pelajaran. Tes yang dipakai untuk mengukur kemampuan siswa, baik kemampuan awal, peningkatan kemampuan siswa selama dilakukan tindakan, dan kemampuan pada akhir siklus tindakan. Tes dilakukan secara tertulis.

Teknik analisa data yang digunakan dalam memperoleh data hasil tindakan yang dilakukan yaitu melalui perhitungan presentase aktivitas hasil belajar siswa, nilai rata-rata kelas dan presentase ketuntasan belajar siswa secara klasikal. 


$$
\begin{aligned}
& \qquad N P=\frac{R}{S M} \times 100 \\
& \text { Keterangan : } \\
& \text { NP : nilai aktifitas yang dicari atau diharapkan. } \\
& \text { R : skor yang diperoleh siswa. } \\
& \text { SM : skor maksimum dari tes yang ditentukan. } \\
& 100 \quad \text { : bilangan tetap }
\end{aligned}
$$

Rumus menghitung presentase aktivitas hasil belajar siswa

$$
X=\frac{\Sigma X_{1}}{N}
$$

$$
\begin{aligned}
& \text { Keterangan: } \\
& \mathrm{X} \text { : rata-rata hitung nilai } \\
& \Sigma \mathrm{X} 1 \text { : nilai siswa } \\
& \mathrm{N} \text { : banyaknya siswa }
\end{aligned}
$$

Rumus menghitung nilai rata-rata kelas

$$
P=\frac{\sum \text { siswa yang tuntas belajar }}{\sum \text { Siswa }} \times 100
$$

Rumus menghitung presentase ketuntasan belajar siswa secara klasikal (Depdikbud, 2001)

\section{Hasil Penelitiam dan Pembahasan}

Penelitian ini dilaksanakan melalui tahap pra siklus, tahap siklus I dan tahap siklus II. Tahap pra siklus dilaksanakan satu hari pada tanggal 31 Januari 2018. Pada tahap pra siklus, peneliti mengajar dengan materi Uang tanpa menggunakan media permainan Let's Play. Berdasarkan hasil pengamatan hasil belajar siswa pada tahap pra siklus, peneliti memperoleh informasi sebagai data awal. Peneliti memperoleh informasi terdapat 27 dari 36 siswa yang hasil belajar nya masih dibawah angka 77 atau dengan kata lain belum mencapai KKM. Rata-rata nilai kelas pada tahap pra siklus sebesar 61,67 dengan presentase kelulusan secara klasikal sebesar 25\%. 
Tahap selanjutnya yaitu tahap Siklus I. Tahap siklus I dilakukan sebanyak 4 pertemuan, dimulai pada tanggal 1 Februari 2018. Pada siklus I ini nilai rata-rata kelas sebesar 74,44 dengan presentase siswa yang mencapai KKM sebanyak 44\%. Hal ini menunjukkan adanya peningkatan belajar dibandingkan pada tahap pra siklus, meskipun belum mencapai target yang diinginkan oleh peneliti. Berdasarkan hasil yang diperoleh pada tahap siklus I, maka dapat dikatakan belum mencapai kriteria keberhasilan tindakan oleh karena itu perlu dilakukannya tahap siklus II, agar hasil belajar siswa dapat meningkat lagi.

Tahap siklus II dilakukan sebanyak 4 pertemuan, dimulai pada tanggal 14 Februari 2018. Pada siklus II ini nilai rata-rata kelas mencapai 84,72 dengan presentase siswa yang mencapai KKM sebesar 88,89\%. Hal ini menunjukkan adanya peningkatan belajar yang sesuai dengan kriteria keberhasilan tindakan yang ditetapkan oleh peneliti

Tahap selanjutnya yaitu tahap Siklus I. Tahap siklus I dilakukan sebanyak 4 pertemuan, dimulai pada tanggal 1 Februari 2018. Pada siklus I ini nilai rata-rata kelas sebesar 74,44 dengan presentase siswa yang mencapai KKM sebanyak 44\%. Hal ini menunjukkan adanya peningkatan belajar dibandingkan pada tahap pra siklus, meskipun belum mencapai target yang diinginkan oleh peneliti.

Tabel 1. Rekapitulasi Rata-rata Nilai Hasil Tes Prasiklus, Siklus I dan Siklus II

\begin{tabular}{ccc}
\hline Pra Siklus & Siklus I & Siklus II \\
\hline 61,67 & 74,44 & 84,72 \\
\hline
\end{tabular}

Sumber: Data Penelitian, 2018

Pada gambar 4 menunjukkan hasil peningkatan nilai rata-rata siswa dari pra siklus, siklus I dan siklus II. Berdasarkan hasil analisis tes pada pra siklus sebesar $25 \%$, lalu hasil analisis tes pada siklus I sebesar $44,44 \%$, hasil tersebut belum mencapai target yaitu dengan KKM 77 dan presentase pencapaian $80 \%$, maka dilakukan tindakan pada siklus II. Pada siklus II hasil belajar 
matematika siswa mencapai $88,89 \%$, maka presentase hasil belajar siswa menunjukan adanya peningkatan sebesar $44,35 \%$ dari siklus I.

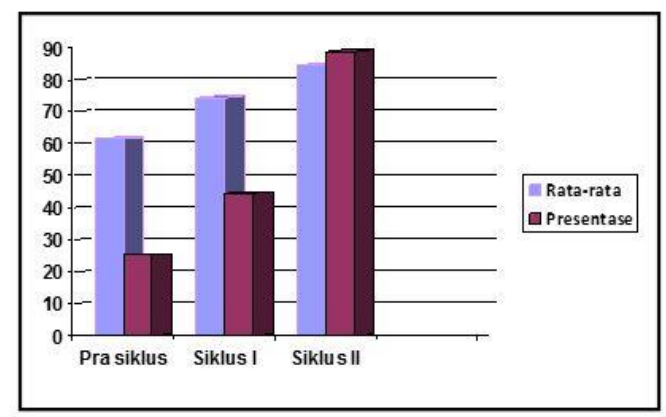

Gambar 4. Rekapitulasi peningkatan hasil belajar siswa pada tahap Pra Siklus, Siklus I dan Siklus II

Dari hasil tes diatas menunjukkan bahwa keberhasilan pembelajaran dari Prasiklus, Siklus I dan Siklus II terlihat berbeda dalam setiap siklusnya. Berdasarkan hasil analisis data pada setiap siklus memberikan informasi bahwa Meningkatkan hasil belajar siswa melalui media permainan Let's Play dapat dikatakan berhasil.

\section{Simpulan}

Penggunaan media pembelajaran khususnya media permainan Let's Play pada mata pelajaran matematika tentang materi Uang, dapat membantu siswa untuk mempelajari dan memahami materi pelajaran dengan mudah karena pertanyaan-pertanyaan yang disajikan dalam media permainan Let's Play berhubungan dengan kehidupan sehari-hari. Berdasarkan hasil analisis, ditemukan bahwa pelaksanaan pembelajaran menggunakan media permainan Let's Play dapat meningkatkan hasil belajar siswa pada setiap siklus serta dari data pengamatan aktivitas guru diperoleh nilai yang terus meningkat dari siklus I ke siklus II.

\section{Daftar Pustaka}

Asra., et al. (2008). Komputer dan Media Pembelajaran di SD. Direktorat Jenderal Pendidikan Tinggi Departemen Pendidikan Nasional. 
Depdikbud, (2001). Kurikulum Pendidikan Dasar: Kurikulum KTSP SD/MI Mata Pelajaran Bahasa Indonesia. Puskur Depdiknas: Jakarta.

Gunadi, Andi Ahmad dan Misriandi. (2014). Pemilihan Media Pembelajaran. Tangerang: UMJ Press

Henry, Samuel. (2010). Cerdas dengan game: panduan praktis bagi orang tua dalam mendampingi anak bermain game. Jakarta: Gramedia Pustaka Utama.

Isjoni. (2008). Pembelajaran Koopertif. Yogyakarta: Pustaka Pelajar.

Sadiman, Arif S.,et al. (2010). Media Pendidikan, Pengertian, Pengembangan, dan Pemanfaatannya. Jakarta: Raja Grafindo Persada

Sanjaya, Wina. (2014). Penelitian Pendidikan: Jenis, Metode dan Prosedur. Jakarta: Kencana Prenada Media Group

Susanto, Ahmad. (2013). Teori belajar E Pembelajaran di Sekolah Dasar. Jakarta: Kencana Prenada Media Group

Winkel, W.S. (2009). Psikologi Pengajaran. Yogyakarta: Media Abadi 